\title{
Causes of Time Overrun in Construction Phase of Building Projects \\ A Case Study on Department of Engineering Services of Sabaragamuwa Provincial Council
}

\author{
D.A.R. Dolage and D.LG. Rathnamali
}

\begin{abstract}
The main purpose of this study is to identify the significant causes of time overrun in construction phase of building projects handled by the Department of Engineering Services (DOES) of Sabaragamuwa Provincial Council (SPC) and to propose mitigative measures. The preliminary investigation of this research revealed that $80 \%$ of the building projects handled by the DOES are not completed within the agreed contract period. The study determines 51 factors causing time overrun in the context of the DOES, which is the basis of the study.
\end{abstract}

The perceptions of clients, consultants and contractors regarding frequency of occurrence and severity of these factors were obtained using questionnaire. Using the indices of frequency, severity and thereby the indices of significance were computed for all the factors. 'Rainy weather', 'poor liquidity of the contractor' and 'inaccurate planning and scheduling of projects are identified by all parties as the most significant factors causing time overrun. According to the views of both clients and consultants, 'contractor related factors' are the most significant causes of time overrun. As for the degree of agreement of perceptions on delay causes. the highest is between clients and consultants $(68 \%)$ and the lowest between the contractors and clients (50\%). Finally, the research makes propositions separately for each party in the contract in order to mitigate the respective contribution towards time overrun

Key Words: Construction Phase, Building Projects, Time Overrun, Causes of Delay

\section{Introduction}

The time overrun in construction projects has become one of the most common problems in the industry that cause multitude of negative effects on the projects and its stakeholders. Therefore, this aspect has been constantly investigated by the researchers across the world with a great enthusiasm.

In Sri Lanka, in a province, the organization responsible for providing infrastructure development such as roads and buildings is its Department of Engineering Services (DOES). Over $90 \%$ of total development budget of the Sabaragamuwa province has been assigned to the DOES to accomplish the given task. It is duty bound to get the maximum usage of the allocated funding by completing projects within the agreed completion date, budget and quality. Nevertheless, it is observed that a large number of building projects undertaken by the DOES are not completed before the deadline. Although a number of studies devoted to investigating causes of time overrun have been conducted locally [eg. Jayawardene and Panditha (2003), Pathiranage and Halwatura (2010) and Jeykanthan, Jayawardena (2012)] evidently, no attempt has been made to explore the causes of delays in state sector building projects let alone the same at provincial level. The objectives of this research are;

1. To identify and evaluate the significance of the factors causing time overrun.

2. To study the differences in perceptions of the three major parties to the contract namely client, consultant and contractor on the factors causing time overrun.

3. To make propositions for each party in the contract to mitigate the individual contribution to time overrun.

\section{Literature Review}

Time overrun in the construction phase of a project can be defined as the non completion of the project within the original or stipulated or

Eng. (Dr.) D. A. R. Dolage, CEng, FIE(Sri Lanka), BSc Eng. (Moratuwa), MSc (Reading), MA (Colombo), MBA (SJP), DBA (UniSA), Senior Lecturer, Department of Civil Engineering, The Open University of Sri Lanka.

Eng. D.LG. Rathnamali CEng, MIE(Sri Lanka), BSc Eng. Hons.(Peradeniya), MTech (OUSL), Design Engineer, Department of Engineering Services, Sabaragamuwa Provincial Council, Sri Lanka. 
agreed contract period. In previous studies, the following definitions have been adopted for time overrun.

- According to Assaf and Al-Hejji (2006), construction time overrun is defined as the time overrun either beyond completion date specified in a contract, or beyond the date that parties agrees upon for delivery of a project.

- $\quad$ According to Aibinu and Jagbro (2002), Delay (time overrun) is a situation where non completion of a project within the original or stipulated or agreed contract period.

The researchers, having recognized the timely deliveries of the project within the budget and to the expected quality are indicators of successful project delivery, explored the factors causing time overrun and proposed mitigative actions. Table 1 presents a summary of the local and international research studies looking into factors causing time overrun; the significant factors found in each study are also listed.

Table 1 - Significant factors causing time overrun identified in past research studies

\begin{tabular}{|c|c|c|}
\hline Researcher & Title & Significant factors \\
\hline $\begin{array}{l}\text { Jayawardene } \\
\text { and Panditha } \\
\text { (2003) }\end{array}$ & $\begin{array}{l}\text { Understanding and } \\
\text { mitigating the factors } \\
\text { affecting construction } \\
\text { delay }\end{array}$ & $\begin{array}{l}\text { Rainy weather, changes by owner and consultant } \\
\text { Manpower shortage, Man power labour skill, } \\
\text { Contractor's cash position, Changes in Foundation } \\
\text { conditions encountered in the field, Changes in water } \\
\text { table condition, Material shortage, equipment shortage, } \\
\text { Obtaining permit from relevant authorities. }\end{array}$ \\
\hline $\begin{array}{l}\text { Pathiranage } \\
\text { and } \\
\text { Halwatura } \\
\text { (2010) }\end{array}$ & $\begin{array}{l}\text { Factors Influencing the } \\
\text { Duration of Road } \\
\text { Construction Projects in } \\
\text { Sri Lanka }\end{array}$ & $\begin{array}{l}\text { Financial problems of the owner as well as the } \\
\text { contractor, Poor site management by the contractor, } \\
\text { Poor weather condition, Contract modification, } \\
\text { Incomplete document/slowness in making decision, } \\
\text { Shortage of site labour and material, Lack of sub } \\
\text { contractor's skill/ poor skills, Construction mistakes } \\
\text { and defective works, Poor site condition }\end{array}$ \\
\hline $\begin{array}{l}\text { Jeykanthan } \\
\text { and } \\
\text { Jayawardena } \\
\text { (2012) }\end{array}$ & $\begin{array}{l}\text { Mitigating delays in } \\
\text { donor funded projects in } \\
\text { Sri Lanka }\end{array}$ & $\begin{array}{l}\text { Inadequate feasibility studies, Errors and omissions in } \\
\text { detail designs, Improperly harmonized procurement } \\
\text { documents, Shortcomings in contract document, } \\
\text { Stakeholder identification and management issues, } \\
\text { Variation and scope changes, Land acquisition and } \\
\text { resettlement, Extreme weather, Shortage of bitumen }\end{array}$ \\
\hline $\begin{array}{l}\text { Mansified et } \\
\text { al. (1994) }\end{array}$ & $\begin{array}{l}\text { Causes of delay and cost } \\
\text { overruns in Nigerian } \\
\text { Construction projects }\end{array}$ & $\begin{array}{l}\text { Financing of and payment for completed project, Poor } \\
\text { contract management, Shortages of material, Price } \\
\text { fluctuations, Inaccurate estimates }\end{array}$ \\
\hline $\begin{array}{l}\text { Assaf and Al- } \\
\text { Hejji (2006) }\end{array}$ & $\begin{array}{l}\text { Causes of delays in } \\
\text { large construction } \\
\text { Projects }\end{array}$ & $\begin{array}{l}\text { Change orders by owners during construction, Delay in } \\
\text { progress payment by owner, Ineffective planning and } \\
\text { scheduling of projects by contractor, Poor site } \\
\text { management and supervision by contractor, Shortage of } \\
\text { labour, Difficulties in financing project by contractor }\end{array}$ \\
\hline $\begin{array}{l}\text { Sambasivan } \\
\text { and Wen } \\
\text { Soon (2006) }\end{array}$ & $\begin{array}{l}\text { Causes and effect of } \\
\text { delays in Malaysian } \\
\text { construction industry }\end{array}$ & $\begin{array}{l}\text { Contractors improper planning, Contractors improper } \\
\text { site management, In adequate contractors experience, } \\
\text { Inadequate client's finance and payments for completed } \\
\text { work, Problems with sub contractors, Shortage of } \\
\text { material, Labour supply, Equipment availability and } \\
\text { failure, Lack of communication between parties, } \\
\text { Mistake during construction stage }\end{array}$ \\
\hline $\begin{array}{l}\text { Sweis et al. } \\
\text { (2007) }\end{array}$ & $\begin{array}{l}\text { Delay in Construction } \\
\text { Projects: in the case of } \\
\text { Jordan. }\end{array}$ & $\begin{array}{l}\text { Financial difficulties faced the contractors, Too many } \\
\text { change orders by the owner, Poor planning and } \\
\text { scheduling of the project by the contractors, Shortage of } \\
\text { man power (skilled, Semi skilled, unskilled) }\end{array}$ \\
\hline $\begin{array}{l}\text { El-Razek et al. } \\
(2008)\end{array}$ & $\begin{array}{l}\text { Causes of Delay in } \\
\text { Building Construction } \\
\text { Projects in Egypt }\end{array}$ & $\begin{array}{l}\text { Financing projects by contractors during construction, } \\
\text { Delay in contractors payment by owner, Design changes } \\
\text { by owners during construction, Partial payments during } \\
\text { construction, Non utilization of professionals during } \\
\text { construction and construction management }\end{array}$ \\
\hline
\end{tabular}


From Table 1, it can be inferred that the significant factors causing time overrun are somewhat common across different countries and industry sectors. Some factors are varying and specific to a country and to an industry sector owing to the differences in socioeconomic and cultural issues in a country or characteristics in an industry sector.

\section{Research Methodology}

This research is conducted by way of a case study involving the building projects executed by the DOES. The data were obtained from the information maintained in the DOES, observations, questionnaires and interviews.

\section{Identification of factors causing time overrun}

At the initial step, 75 factors causing the time overrun were identified from both local and international research studies. These factors were categorized into five major groups: client related, contractor related, consultant related, and contractual relationship related and external. Interviews were conducted for both consultants and the contractors involved in 40 delayed projects executed by the DOES. The main purpose of these interviews was to distill a list of factors causing time overrun, which are appropriate to the building construction projects undertaken by the DOES. With the aid of these interviews, it was possible to shortlist 51 delay factors appropriate for the projects undertaken by the DOES.

\section{Questionnaire design}

In order to evaluate significance of factors causing time overrun, a questionnaire survey was conducted. A questionnaire which was designed using the short listed 51 delay factors was aimed at identifying the frequency of occurrence, severity and significance, with regard to each factor. The questionnaire comprised two sections: Section I being devoted to the collection of general information concerning respondents; Section II being devoted to include the list of identified causes of time overrun. The respondents were requested to give their response to each delay cause, based on their experience with the projects handled by the DOES, with respect to the following statements: The frequency of occurrence of the delay cause is high; The severity of the delay cause is high. The responses could be indicated on a five point Likert scale as follows; strongly disagree (1), disagree (2), neutral (3), agree (4), strongly agree (5). The questionnaires were distributed to clients (Secretaries of Provincial Ministries or Heads of Departments), consultants (Engineers and senior technical officers of the DOES), Contractors (those who regularly work with the DOES). The respondents of the questionnaire survey included 10 clients, 23 consultants and 23 contractors who have had a considerable experience working with the building projects undertaken by the DOES.

\section{Approach to data analysis}

The data collected through the questionnaire survey were used to compute the following indices:

Frequency Index (F.I): FI was computed for each factor using Equation 1.

Frequency Index

(F.I.) $=\sum(\mathrm{an} / 5 \mathrm{~N}) \times 100$

Where $a$ - Value representing weighting given to each response, ranging from 1 (strongly disagree) to 5 (strongly agree), n- The frequency of responses, $\mathrm{N}$-Total no of responses

Severity Index: (SE.I): SE.I was computed for each factor using Equation 2.

Severity Index

(SE.I.) $=\sum(\mathrm{an} / 5 \mathrm{~N}) \times 100$

Where $\boldsymbol{a}$ - Value representing weighting given to each response, ranging from 1 (strongly disagree) to 5 (strongly agree), n- The frequency of responses, N-Total no of responses

\section{Significance Index (SI.I)}

The Significance Index of each cause is calculated as a product of frequency and severity indices as shown in Equation 3.

Significance Index

$($ SI.I $)=[($ F.I. $) \times($ SE.I. $)] / 100$

\section{Spearman's rank correlation}

In the study of Assaf and Al-Hejji (2006), on causes of delays in large construction projects, the agreement on perceptions between two respondent parties has been evaluated by using Spearman rank correlation coefficient. The same coefficient has been adopted in this study to compare the agreements between perceptions among parties. The Spearman's correlation coefficient $r$ is used to measure and compare the association between the rankings of two parties for all the factors causing time overrun, while ignoring the third party. It is calculated using Equation 4:

$r_{\mathrm{s}}=1-\left[\left(6 \sum \mathrm{d}^{2}\right) /\left(\mathrm{n}^{3}-\mathrm{n}\right)\right]$

$r_{s}$ - Spearman rank correlation coefficient between two parties, 
d - Difference between ranks assigned to factors causing time overrun for each cause $\mathrm{n}$ - Number of pairs of rankings.

The coefficients vary between +1 to -1 , where +1 implies a highly strong agreement and -1 implies a highly strong disagreement.

It was necessary to mitigate the effects of the top ten significant factors causing time overrun. In order to propose mitigative measures in the context of the DES, a series of interviews were conducted with the experts associated with the DES.

\section{Results and Discussion}

\subsection{Identification and evaluation of factors} causing time overrun

The analysis of the durations of the completed projects revealed that 80 per cent are not completed within the agreed contract period
The 51 factors causing time overrun, selected through the interviews with the expert associated with the building projects undertaken by the DOES are displayed in Table 2. Based on the responses made by the each party the indices for severity, frequency and thereby the significance were computed with respect to each delay cause. Table 2 also depicts the SI.I and the ranking based on the perceptions of clients, consultants and contractors. Table 3 shows the top 10 most significant factors causing time overrun based on the perceptions of each party, factors having been extracted from Table 2. All the parties have recognized that 'Rainy weather', 'poor liquidity of the contractor' and 'inaccurate planning and scheduling of projects' are among the ten most significant factors causing time overrun.

Table 2 -Significance and ranking of factors causing time overrun

\begin{tabular}{|c|c|c|c|c|c|c|c|}
\hline \multirow{2}{*}{$\begin{array}{l}\text { S. } \\
\text { No. }\end{array}$} & \multirow[t]{2}{*}{ Factors causing time overrun } & \multicolumn{2}{|c|}{$\begin{array}{l}\text { Client 's } \\
\text { Perception }\end{array}$} & \multicolumn{2}{|c|}{$\begin{array}{l}\text { Consultant's } \\
\text { Perception }\end{array}$} & \multicolumn{2}{|c|}{$\begin{array}{l}\text { Contractor's } \\
\text { Perception }\end{array}$} \\
\hline & & SI.I & Rank & SI.I & Rank & SI.I & Rank \\
\hline & Client related causes & 38.62 & & 45.78 & & 34.67 & \\
\hline 1 & Selection of non feasible projects & 40.96 & 33 & 43.34 & 28 & 20.44 & 42 \\
\hline 2 & Delay in progress payments & 57.76 & 14 & 68.06 & 1 & 87.38 & 1 \\
\hline 3 & Change orders by the clients during construction & 39.68 & 36 & 54.22 & 13 & 37.04 & 19 \\
\hline 4 & Unrealistically short project duration & 36.96 & 40 & 43.34 & 29 & 21.64 & 36 \\
\hline 5 & Too many projects being handled at a time & 28.08 & 49 & 26.26 & 49 & 18.53 & 42 \\
\hline 6 & $\begin{array}{l}\text { Awarding new projects exceeding budgetary } \\
\text { allocation }\end{array}$ & 32.48 & 47 & 53.67 & 14 & 39.73 & 16 \\
\hline \multirow[t]{3}{*}{7} & Delay in site handing over to the contractor & 36.96 & 41 & 37.51 & 41 & 35.93 & 22 \\
\hline & Consultant related causes & 49.82 & & 41.11 & & 27.18 & \\
\hline & Designing and Estimation & 47.31 & & 40.84 & & 32.88 & \\
\hline 8 & Delay in producing design documents & 62.32 & 11 & 46.69 & 22 & 20.53 & 39 \\
\hline 9 & $\begin{array}{l}\text { Delay in approving major changes in the scope of } \\
\text { work }\end{array}$ & 57.76 & 15 & 51.33 & 16 & 52.63 & 7 \\
\hline 10 & Mistakes and discrepancies in design documents & 44.88 & 26 & 40.08 & 38 & 36.93 & 20 \\
\hline 11 & Unclear and inadequate details in drawings & 43.52 & 28 & 36.50 & 43 & 20.04 & 40 \\
\hline 12 & $\begin{array}{l}\text { Mismatch of type drawings to the site conditions } \\
\text { (Eg. School buildings) }\end{array}$ & 29.16 & 48 & 23.76 & 50 & 11.71 & 49 \\
\hline \multirow[t]{2}{*}{13} & Insufficient/inaccurate information for estimation & 46.24 & 24 & 46.67 & 23 & 55.44 & 6 \\
\hline & Monitoring and Controlling & 51.59 & & 42.15 & & 25.75 & \\
\hline 14 & Insufficient controlling and monitoring & 68.88 & 4 & 45.56 & 26 & 18.90 & 41 \\
\hline 15 & Failure to give expedient solutions to problems & 56.24 & 18 & 42.25 & 31 & 52.09 & 9 \\
\hline 16 & Political influence & 42.16 & 32 & 45.53 & 27 & 18.37 & 43 \\
\hline 17 & Delay in quality assurance/control & 27.04 & 50 & 32.54 & 47 & 7.02 & 50 \\
\hline 18 & $\begin{array}{l}\text { Long waiting time for approval of tests and } \\
\text { inspection }\end{array}$ & 43.56 & 27 & 30.69 & 48 & 16.70 & 46 \\
\hline 19 & Slow decision making & 59.28 & 13 & 42.22 & 33 & 43.10 & 13 \\
\hline \multirow[t]{2}{*}{20} & Inadequate staff & 63.96 & 9 & 56.22 & 11 & 24.09 & 34 \\
\hline & Payments & 61.72 & & 42.90 & & 43.25 & \\
\hline 21 & Delay in approving payments & 56.24 & 19 & 38.53 & 40 & 30.47 & 29 \\
\hline \multirow[t]{2}{*}{22} & Delay in approving extra work and variations & 67.20 & 6 & 47.26 & 19 & 56.03 & 5 \\
\hline & Others & 45.50 & & 39.72 & & 16.91 & \\
\hline 23 & $\overline{\text { Conflict with contractors }}$ & 40.60 & 35 & 33.40 & 45 & 16.43 & 47 \\
\hline 24 & Poor coordination with contractors & 50.40 & 22 & 46.04 & 25 & 17.39 & 44 \\
\hline
\end{tabular}




\begin{tabular}{|c|c|c|c|c|c|c|c|}
\hline \multirow{2}{*}{$\begin{array}{l}\text { S. } \\
\text { No. }\end{array}$} & \multirow{2}{*}{ Factors causing time overrun } & \multicolumn{2}{|c|}{$\begin{array}{l}\text { Client 's } \\
\text { Perception }\end{array}$} & \multicolumn{2}{|c|}{$\begin{array}{l}\text { Consultant's } \\
\text { Perception }\end{array}$} & \multicolumn{2}{|c|}{$\begin{array}{l}\text { Contractor's } \\
\text { Perception }\end{array}$} \\
\hline & & SI.I & Rank & SI.I & Rank & SI.I & Rank \\
\hline & Contractor related causes & 52.14 & & 48.97 & & 34.18 & \\
\hline & Material & 37.80 & & 35.38 & & 30.06 & \\
\hline 25 & Low quality of material & 50.40 & 23 & 41.69 & 35 & 47.07 & 11 \\
\hline 26 & Shortage of material in the market & 43.52 & 29 & 42.22 & 32 & 59.86 & 4 \\
\hline 27 & $\begin{array}{l}\text { Changes in material types and specifications } \\
\text { during the construction }\end{array}$ & 35.84 & 44 & 33.53 & 44 & 21.64 & 37 \\
\hline 28 & Delay in material delivery & 38.08 & 38 & 36.98 & 42 & 17.01 & 45 \\
\hline \multirow[t]{2}{*}{29} & Damages to the material in transport and storages & 21.16 & 51 & 22.50 & 51 & 4.73 & 51 \\
\hline & $\underline{\text { Human Resources }}$ & 60.62 & & 55.10 & & 46.72 & \\
\hline 30 & Unavailability of experienced technical staff & 75.44 & 2 & 60.06 & 6 & 36.48 & 21 \\
\hline 31 & Scarcity of skill labourers & 56.24 & 20 & 58.77 & 8 & 46.59 & 12 \\
\hline 32 & Shortage of labourers & 57.76 & 16 & 53.17 & 15 & 61.88 & 3 \\
\hline 33 & $\begin{array}{l}\text { Low productivity level of labourers. } \\
\text { Plant E Equipment }\end{array}$ & 53.04 & 21 & 48.42 & 17 & 41.92 & 14 \\
\hline \multirow[t]{2}{*}{34} & Low productivity and efficiency of equipment & 35.96 & 43 & 41.17 & 37 & 13.43 & 48 \\
\hline & Management & 69.01 & & 59.90 & & 43.88 & \\
\hline 35 & Inaccurate planning and scheduling & 79.20 & 1 & 61.35 & 4 & 49.60 & 10 \\
\hline 36 & Ineffective time management & 65.60 & 7 & 58.78 & 7 & 38.61 & 17 \\
\hline 37 & Poor site management and supervision & 67.24 & 5 & 57.51 & 9 & 35.39 & 25 \\
\hline \multirow[t]{2}{*}{38} & Poor liquidity & 64.00 & 8 & 61.97 & 3 & 51.90 & 9 \\
\hline & Other & 53.34 & & 54.51 & & 31.91 & \\
\hline 39 & $\overline{\text { Contractors with political clout }}$ & 42.16 & 31 & 41.57 & 36 & 25.07 & 33 \\
\hline 40 & Inadequate experience & 43.52 & 30 & 55.63 & 12 & 35.39 & 24 \\
\hline 41 & Excessive work in hand & 62.40 & 10 & 63.97 & 2 & 41.41 & 15 \\
\hline 42 & Delay in mobilization & 60.84 & 12 & 56.88 & 10 & 30.00 & 30 \\
\hline 43 & $\begin{array}{l}\text { Rework due to mistakes and defects in } \\
\text { construction }\end{array}$ & 57.76 & 17 & 47.25 & 20 & 27.67 & 32 \\
\hline & Contractual relationship & 39.06 & & 43.46 & & 30.42 & \\
\hline 44 & $\begin{array}{l}\text { Errors, Discrepancies and omissions in contract } \\
\text { document }\end{array}$ & 36.00 & 45 & 33.03 & 46 & 23.71 & 35 \\
\hline 45 & Nonpayment of mobilization advance & 33.60 & 55 & 47.18 & 21 & 31.83 & 28 \\
\hline 46 & Ineffective delay penalties & 46.20 & 25 & 46.13 & 24 & 28.51 & 31 \\
\hline 47 & $\begin{array}{l}\text { Non standard awarding practices (negotiation to } \\
\text { lower the bid price) }\end{array}$ & 40.96 & 34 & 48.42 & 18 & 38.56 & 18 \\
\hline & External & 44.51 & & 45.84 & & 44.83 & \\
\hline 48 & $\begin{array}{l}\text { Unexpected ground conditions (eg. soil, high water } \\
\text { table...etc) }\end{array}$ & 37.12 & 39 & 43.33 & 30 & 31.95 & 27 \\
\hline 49 & Restricted access to the site and surroundings & 39.60 & 37 & 41.69 & 34 & 35.46 & 23 \\
\hline 50 & Restricted space for operations / material storage & 33.60 & 46 & 39.06 & 39 & 33.94 & 26 \\
\hline 51 & Rainy weather. & 72.24 & 3 & 60.71 & 5 & 87.36 & 2 \\
\hline
\end{tabular}

There are other factors, significance of which have been recognized to be among the top ten most significant factors causing time overrun by two parties: 'delay in progress payment by clients', 'unavailability of competent experienced technical staff', 'excessive work in hands of contractors', 'poor site management and supervision', 'delay in approving extra work and variation', 'ineffective time management'. This results in ten significant factors important to all parties, which are displayed in Table 4 . Table 4 also displays a brief description of the nature of each factor causing time overrun

Table 3- Most significant factors causing time overrun according to perceptions of each party

$\begin{array}{clll}\text { Rank } & \text { Clients' perception } & \text { Consultants' perception } & \begin{array}{l}\text { Contractors' perception } \\ \text { Delay in progress paymen }\end{array} \\ 2 & \begin{array}{l}\text { Inaccurate planning and } \\ \text { scheduling of contractor }\end{array} & \begin{array}{l}\text { Delay in progress payments } \\ \text { by client }\end{array} & \begin{array}{l}\text { Unavailability of } \\ \text { experienced technical staff of }\end{array} \\ \text { contractor } & \begin{array}{l}\text { Excessive work in hand of } \\ \text { contractor }\end{array} & \text { Rainy weather } \\ \text { Rainy weather } & \text { Poor liquidity of contractor } & \begin{array}{l}\text { Shortage of Labourers of } \\ \text { contractor }\end{array}\end{array}$


Insufficient controlling and monitoring of consultant

5 Poor site management and supervision of contractor

6 Delay in approving extra work and variations by consultant

7 Ineffective time management of contractor

8 Poor liquidity of contractor

9 Inadequate staff of consultant

10 Excessive work in hand of contractor
Inaccurate planning and scheduling of contractor Rainy weather

Unavailability of experienced technical staff of contractor

Ineffective time management of contractor

Scarcity of skill labourers of contractor

Poor site management and supervision of contractor Delay in mobilization of contractor
Shortage of material in the market

Delay in approving extra

work and variations by

consultant

Insufficient/inaccurate

information for estimation

Delay in approving major changes in the scope of work

Failure to give expedient solutions to problems

Poor liquidity of contractor

Inaccurate planning and scheduling of contractor

Table 4- Nature of ten significant factors causing time overrun

\begin{tabular}{|c|c|}
\hline Factor & Nature of the factor \\
\hline $\begin{array}{l}\text { 1.Delay in progress } \\
\text { payment by clients }\end{array}$ & $\begin{array}{l}\text { Frequently happens. } \\
\text { When the contractor gets the wind of the financial crisis a client is in, he may be } \\
\text { induced to delay the construction work deliberately. }\end{array}$ \\
\hline $\begin{array}{l}\text { 2.Inaccurate planning } \\
\text { and scheduling of } \\
\text { projects by } \\
\text { contractors }\end{array}$ & $\begin{array}{l}\text { Often fails to draw up practicable and user-friendly "work programmes due to lack of } \\
\text { knowledge in construction management techniques. } \\
\text { Tends to submit work programmes which are not accurate but just satisfies the } \\
\text { requirements in condition of contract }\end{array}$ \\
\hline 3.Rainy weather & $\begin{array}{l}\text { Prevails over longer periods of the year } \\
\text { The planning process (designing, estimating, sanctioning and procurement work, etc ) } \\
\text { starts after the provincial budget get approved. in March. So the projects may start in } \\
\text { the rainy season as half of the year is spent on the above. } \\
\text { Although predicable to some extent, the scant attention is paid during the planning } \\
\text { stage by contractors }\end{array}$ \\
\hline $\begin{array}{l}\text { 4.Non availability of } \\
\text { experienced technical } \\
\text { staff of contractor }\end{array}$ & $\begin{array}{l}\text { At the biding stage, contractors claim to be having qualified staff } \\
\text { Do not employ adequate number of skilled technical staff } \\
\text { Projects are handled by foremen not having adequate technical experience } \\
\text { Due to the current demand, retention of technical staff is difficult } \\
\text { Creates a communication gap between the consultants and contractors }\end{array}$ \\
\hline $\begin{array}{l}\text { 5.Excessive work in } \\
\text { hand of the contractors }\end{array}$ & $\begin{array}{l}\text { Frequently happens } \\
\text { Too many contracts can be awarded to the same contractor by different clients. } \\
\text { As contractors tend to bid for as many contracts as possible, one may end up being } \\
\text { awarded too many projects. } \\
\text { No central unit receive contract awarding details }\end{array}$ \\
\hline $\begin{array}{l}\text { 6.Poor liquidity of } \\
\text { contractors }\end{array}$ & $\begin{array}{l}\text { Contractors having liquidity problems may win contracts as financial status is not } \\
\text { checked at the tender evaluation; only go by the bid price } \\
\text { Non payment of mobilization advance make matters worse } \\
\text { Delays in payment of progress payments aggravates the problem }\end{array}$ \\
\hline 7.Shortage of labourers & $\begin{array}{l}\text { Due to the boom in construction industry demand has exceeded the supply. } \\
\text { The potential labour force is not attracted to the construction industry. } \\
\text { Opportunities are available for skilled workers overseas at a much higher salary }\end{array}$ \\
\hline $\begin{array}{l}\text { 8. Delay in approving } \\
\text { extra work and } \\
\text { variation }\end{array}$ & $\begin{array}{l}\text { The majority of engineers and contractors do not follow proper procedure and format } \\
\text { for submission of extra work and variations for approval. } \\
\text { Authority for approving extra work and variation is kept with the clients. Non } \\
\text { delegation of authority for approving has made the process too long and tedious. }\end{array}$ \\
\hline $\begin{array}{l}\text { 9.Poor site } \\
\text { management and } \\
\text { supervision of } \\
\text { contractors }\end{array}$ & Many contractors are poor in planning, organizing, staffing, directing and controlling \\
\hline $\begin{array}{l}\text { 10.Ineffective time } \\
\text { management of } \\
\text { contractors }\end{array}$ & $\begin{array}{l}\text { Most of the projects are under-staff and the contractor himself is handling planning, } \\
\text { purchasing, supervision, etc } \\
\text { Contractors may be heavily burdened with internal and external communications, } \\
\text { conflict resolution, meetings, and report preparation }\end{array}$ \\
\hline
\end{tabular}


The factors causing time overrun can be further analyzed in terms of the five groups, based on perceptions of all the parties. The group significance index is calculated by taking the average of the indices of the sub factors in each group. Ranking of these groups with respect to significance, based on perceptions of clients, consultants, contractors are presented in Table 5. As shown in Table 5, both clients and consultants indicate factors related to the contractors are the top most cause of time overrun and in contrast, factors related to them are the least significant.

Table 5 - Ranking of significance of groups of factors

\begin{tabular}{lcccccc}
\hline Group & \multicolumn{2}{c}{ Client } & \multicolumn{2}{c}{ Consultant } & \multicolumn{2}{c}{ Contractor } \\
& SI. I & Rank & SI. I & Rank & SI. I & Rank \\
\hline Client related factors & 38.62 & 5 & 45.78 & 3 & 34.67 & $\mathbf{2}$ \\
Consultant related factors & 49.82 & 2 & 41.11 & 5 & 27.18 & 5 \\
Contractor related factors & 52.14 & 1 & 48.97 & 1 & 34.18 & 3 \\
Contractual relationship & 39.06 & 4 & 43.46 & 4 & 30.42 & 4 \\
External factors & 44.51 & 3 & 45.84 & 2 & 44.83 & 1 \\
\hline
\end{tabular}

As for the contractors, the external factors are the top most cause for time overrun. As pointed out by all the parties, contractual relationship related factors are of least significance for time overrun. All the parties have also agreed that the external factors are important causes to reckon with.

\subsection{Agreement on perceptions of parties on factors causing time overrun}

The rank correlation coefficients between two parties for all combinations for selected groups of factors are depicted in Table 6 .

Table 6- Rank Correlation between parties

\begin{tabular}{|c|c|c|c|c|}
\hline Factors & Party & $C^{\prime}$ ent & C'ant & $C^{\prime}$ tor \\
\hline \multirow[t]{3}{*}{ All } & $C^{\prime}$ ent- & 1.0 & 0.68 & 0.50 \\
\hline & C'ant & 0.68 & 1.0 & 0.64 \\
\hline & $C^{\prime}$ tor & 0.50 & 0.64 & 1.0 \\
\hline \multirow[t]{3}{*}{ C'ent } & C'ent- & 1.0 & 0.71 & 0.39 \\
\hline & $C^{\prime}$ ant & 0.71 & 1.0 & 0.82 \\
\hline & $C^{\prime}$ tor & 0.39 & 0.82 & 1.0 \\
\hline \multirow[t]{3}{*}{ C'ant } & C'ent- & 1 & 0.76 & 0.64 \\
\hline & C'ant & 0.76 & 1 & 0.65 \\
\hline & $C^{\prime}$ tor & 0.64 & 0.65 & 1 \\
\hline \multirow[t]{3}{*}{$C^{\prime}$ tor } & C'ent- & 1 & 0.89 & 0.54 \\
\hline & C'ant & 0.89 & 1 & 0.60 \\
\hline & $C^{\prime}$ tor & 0.54 & 0.60 & 1 \\
\hline
\end{tabular}

C'ent-Client, C'ant -Consultant, C'tor-Contractor

When all factors are considered, a strong agreement on perceptions can be observed between clients and consultants. The consultants and contractors also show a strong agreement on their perceptions. On the contrary, a mediocre agreement can be observed between clients and contractors. With regard to factors related to client, contractors have a very low agreement with the clients, whereas consultants have a strong agreement with clients.

A strong correlation can be observed for consultants with both clients and contractors regarding consultant related factors. As for contractor related factors, there is a strong correlation between contactors and consultants. Further, the correlation between perceptions of contractors and consultants are moderate with regard to contractor related factors. As all the rank coefficients are positive, it is construed that there is a fairly strong agreement among perceptions of different parties. However, this could also indicate the tendency of one party finding fault with another.

\subsection{Commonality of significant delay factors among studies investigating delay factors}

The commonality of the ten significant delay factors found in this study was assessed with respect to the significant delay factors found in the eight other local and foreign research studies; Table 1 showed the list of significant delay factors found in eight other local and international research studies. The distribution of the ten significant factors in the eight studies is depicted in Table 7. 
Table 7- Distribution of Significant Delay factors

\begin{tabular}{|l|c|c|}
\hline Factor & Local & International \\
\hline $\begin{array}{l}\text { Delay in progress } \\
\text { payment by clients }\end{array}$ & 2 & 4 \\
\hline $\begin{array}{l}\text { Inaccurate planning and } \\
\text { scheduling of projects by } \\
\text { contractors }\end{array}$ & 0 & 3 \\
\hline Rainy weather & 3 & 0 \\
\hline $\begin{array}{l}\text { Non availability of } \\
\text { experienced technical } \\
\text { staff of contractor }\end{array}$ & 0 & 1 \\
\hline $\begin{array}{l}\text { Excessive work in hand of } \\
\text { the contractors }\end{array}$ & 0 & 0 \\
\hline $\begin{array}{l}\text { Poor liquidity of } \\
\text { contractors }\end{array}$ & 2 & 3 \\
\hline Shortage of labourers & 0 & 0 \\
\hline $\begin{array}{l}\text { Delay in approving extra } \\
\text { work and variation }\end{array}$ & 1 & 3 \\
\hline $\begin{array}{l}\text { Poor site management } \\
\text { and supervision of } \\
\text { contractors }\end{array}$ & 0 & 0 \\
\hline $\begin{array}{l}\text { Ineffective time } \\
\text { management of } \\
\text { contractors }\end{array}$ & & \\
\hline
\end{tabular}

The assessment of commonality of significant delay factors of this study with those of other studies is a useful exercise. Nevertheless, this has to be done carefully, due to the contextual differences among studies. The contextual differences occur in terms of differences in country, industry sub sector, and methodology. This situation may render a detailed assessment a futile exercise and hence only an overview would suffice. According to Table 7, each factor, 'Delay in progress payment by clients', 'Poor liquidity of contractors' and 'Shortage of labourers' are common because each has been identified in at least 5 studies. In four studies, 'Poor site management and supervision of contractors' has been picked as a significant factor of delay. Hence, it can be stated that these four factors are significant common factors delaying construction projects. Since, each factor, 'Inaccurate planning and scheduling of projects by contractors and Rainy weather have been recognised in three studies, they are not sufficiently common. The factors, 'Non availability of experienced technical staff of contractors', 'Excessive work in hand of the contractors' Delay in approving extra work and variation' and 'Ineffective time management of contractors' are either not listed at all or only once among the significant factors. This implies that these factors are unique to this particular study because in the provincial set up these are sensitive and have high potential for impact on delay.

\section{Conclusion and Recommendations}

The research has identified 51 potential factors responsible for the time overrun in the building construction projects undertaken by the DOES. The most significant factors causing time overrun identified in this research based on the perceptions of all three main parties to the contract namely clients, consultants and contractors are as follows:

(1)Delay in progress payment by clients, (2) Inaccurate planning and scheduling of projects by contractors, (3) Rainy weather, (4) Unavailability of experienced technical staff, (5) Excessive work in hand of the contractors, (6) Poor liquidity of contractors, (7) Shortage of labourers, (8) Delay in approving extra work and variation (9) Poor site management and supervision of contractors (10) Ineffective time management of contractors. Going by the views of both clients and consultants, contractor related factors are the most significant for time overrun. The contractors indicate that external factors are the significant factors for time overrun.

The Spearman's rank correlation coefficients show that there exists a reasonably strong agreement between each two groups of parties on ranking of the significance of delay causes. The highest degree of agreement (68\%) is between clients and consultants, while the lowest $(50 \%)$ is between clients and contractors. All rank coefficients are positive for each group of factors causing time overrun, which indicates a fairly strong agreement between perceptions of each party

The research makes recommendations in general and particularly to all the parties for mitigating factors causing time overrun based on expert opinion. The recommendations are made in the context of building construction projects undertaken by the DOES. As the management systems and implementing procedures are similar across all the government institutions in Sri Lanka, the recommendations could be applicable with slight modifications by other government institutions.

\section{General recommendations}

1 The SPC should form a central unit attached to a relevant provincial ministry, assigned with the task of maintaining a 
database which would maintain information pertaining to the past performance of contractors. All provincial ministries should feed this unit with information regarding awarding of contracts, termination of contracts and other pertinent information.

2 The provincial ministries should consider paying the mobilization advance to contractors having taken all precautionary measures to ensure easy reclaiming.

3 Instruction to Bidders should be amended to include clauses that would allow the client discretion to avoid having to award the contract to an unrealistically low bid. The margin of discretion should be within a band, the floor of which should be evaluated based on previous experience. Nevertheless, in cases where the bid value is unrealistically low, the bidders can submit an acceptable justification for the contract to be considered for an award.

4 The currently practiced process of negotiation with the lowest bidder to bring down the bid value to the engineers estimate is not recommended.

5 If the projects are awarded based on the value of engineer's estimates, in calculation of price adjustment, base indices should be computed on the prices that prevailed one month prior to the month on which the BSR is prepared.

6 With regard to delays in progress payments, delay claims (interest for the delayed payments) should be granted for the contractors in lieu of time extensions as stipulated in the conditions of contracts.

7 The salaries of technical staff of the contractors should be included in the BOQ as a management fee instead of as an integral part of the overhead.

8 The authority for approving extra works and variations should be delegated to the consultant as specified in the conditions of contract, instead of the practice of resting it with the client.

9. The clients, consultants and contractors should keep themselves abreast of recent developments in Construction Management and Contract Law by undergoing training programmes and workshops.

10. Opportunities for gaining technical knowledge for Skilled Labourers should be established by the government and a grading system for Skilled Labourers should be established at the national level.

\section{Recommendations to Client}

1 Needs to ensure that sufficient funds are available for uninterrupted payments before awarding the contract.

2 Needs to take adequate care in preparing a sound 'project brief' by involving a wide range of stakeholders to identify their requirements.

3 Needs to make sufficient time available for consultants to do a proper design.

4 Needs to take into account the weather pattern of the region in preparing the year plan of development work of provincial ministries.

5 Should forward the cash flow forecasting to the Treasury in advance and thereafter should follow it up in order to get the payments released on schedule.

\section{Recommendations to Consultant}

1 Should hold a sufficient number of design review sessions with the client before finalizing the design.

2 The estimates should be reviewed by a team of consultants, comprising engineers, architects and quantity surveyors, before tendering. Should take utmost care in preparing the estimates and the number of provisional sum items in the estimate should be minimized.

3 Improve the existing process of monitoring and controlling in order to have close inspections at appropriate stages, to detect potential problems in time and to draw the immediate attention of higher management.

4 Expedite the approval process, strictly adhering to the existing procedure.

\section{Recommendations to Contractor}

1. Be conversant with contractual matters and contractual rights stipulated in the conditions of contract.

2. Be wary of the behavior of the market and maintain buffer stocks of material in keeping with the scheduling of project procurement plan.

3. Need to manage financial resources efficiently including the efficient cash flow management using the progress payments.

4. Projects should be properly planned and scheduled considering the availability of resources, weather patterns and realistic time allocation for tasks. 
5. Extra work and variation should not be undertaken without a formal request from the client or the consultant. The approval for extra work and variation should be requested as specified in the contract document.

6. Every attempt must be made to retain the same labour gang throughout project duration.

\section{References}

1. Aibinu A.A. and Jagboro G. O. (2002), The effect of construction delays on project delivery in Nigerian construction industry, International Journal of Project Management, 20, 593-599.

2. Assaf S.A., Al-Hejji S. (2006), Causes of delays in large construction Projects, International Journal of Project Management, 24(4), 349-357.

3. Dolage D.A.R and Perera P.W.S (2009), Delays in the Pre Construction Phase of State Sector Building Projects, EngineerJournal of Institution of Engineers Sri Lanka, Vol.XXXXII (3), 22-30.

4. El-Razek M.E.Abd., Bassioni H.A. and Mobarak A.M. (2008), Causes of Delay in Building Construction Projects in Egypt, Journal of Construction Engineering and Management, 134(11) 831-841.

5. ICTAD, Standard Bidding Document for Major Contract, $2^{\text {nd }}$ Edition Revised EditionJanuary 2007.

6. ICTAD, Standard Bidding Document for Minor Contract, $2^{\text {nd }}$ Edition Revised Edition January 2007.

7. ICTAD, Formula Method for Determining the Adjustment to Contract Sum due to fluctuation in prices, Revised Edition September 1998
8. Oberlender G. D., (1993), Project Management for Engineering and Construction. McGraw-Hill, Inc.

9. Jayawardene A.K.W. and Panditha H.G.W. (2003), Understanding and Mitigating the Factors Affecting Construction Delay, Engineer-Journal of Institution of Engineers Sri Lanka, XXXV1 (02), 07-14.

10. Jeykanthan J. and Jayawardena A.K.W., (2012), Mitigating Delays in Donor Funded Projects in Sri Lanka, Engineer-Journal of Institution of Engineers Sri Lanka, XXXXV (01), 65-75.

11. Kaliba C., Muya M., Mumba K. (2009), Cost Escalation and Schedule Delays in Road Construction Projects in Zambia, "Science Direct" International Journal of Project Management, 27, 522-531.

12. Mansified N.R. and Ugwu O.O., Doran T. (1994), Causes of Delay and Cost Overruns in Nigerian Construction Projects, International Journal of Project Management, 12(4), 254-260.

13. MEI paper on Spearman's Rank Correlation Coefficient, December 2007.

14. National Procurement Agency (2006), Procurement Manual for Goods and Works.

15. National Procurement Agency (2006), Procurement Guide Line for Goods and Works.

16. Pathiranage Y.L., and Halwatura R.U., (2010) Factors Influencing the duration of Road Construction Projects in Sri Lanka, Engineer-Journal of Institution of Engineers Sri Lanka, XXXXIII(04), 17-30.

17. Sambasivan M., Soon Y. W. (2006), Causes and Effect of Delays in Malaysian Construction Industry, International Journal of Project Management, 25, 517-526.

18. Sweis G., Sweis R., Hammad A. A. and Shboul A. (2008), Delay in Construction Projects: The Case of Jordan, International Journal of Project Management, 26, 665-674. 